\title{
POR QUE LITERATURA AFRICANA DE EXPRESSÃO GREGA?: enfrentando uma questão
}

Fernanda Lemos de Lima

(UERJ)

https://orcid.org/0000-0001-8223-6372

\section{RESUMO}

Este artigo objetiva destacar a expressão grega existente na Literatura Africana, ao mesmo tempo que evidencia um posicionamento sobre os conteúdos literários por vezes segregados do âmbito da Literatura Africana por estarem atrelados a nomes comumente associados ao mundo helênico. Desse modo, propõe-se ultrapassar não apenas as concepções sobre o que define a Literatura Africana de expressão helênica para além da utilização da língua grega, na qual o conteúdo literário fora produzido. Também se busca evidenciar que os encontros ocorridos entre etnias, na África da Antiguidade, não deixam de ser demonstrados nessa literatura, como percebido no "romance grego". Assim, é possível apontar a troca entre essas culturas e como elas se tornaram próximas e, às vezes, extremamente inter-relacionadas. Contudo, as abordagens histórico-literárias deixam de transparecer essa imbricação ao rotulá-las como "gregas" ou seus autores como "gregos de". Diante de um complexo contexto, coloca-se a questão central para a reflexão: em que medida a literatura feita no chamado período Alexandrino/ Helenístico pode ser considerada ou rotulada apenas de "grega"? A partir dessa indagação, vamos retornar a Heródoto e a teóricos como Maria Regina Cândido e Susan Stephens para destrinchar o tema.

PALAVRAS-CHAVE: eurocentrismo; Antiguidade; período helenístico; Literatura Africana; romance grego 


\section{WHYAFRICANLITERATUREOFGREEKEXPRESSION?: facing a question}

\section{ABSTRACT}

This article aims to highlight the Greek expression in African literature, showing at the same time a position on the literary contents sometimes segregated from the scope of African literature for being linked to names commonly associated with the Hellenic world. Thus, it is proposed to surpass not only the conceptions on what defines African literature of Greek expression beyond the use of the Greek language in which the literary content was produced, but it also seeks to show that the encounters between ethnic groups in Ancient Africa are evident in this literature, as perceived in the "Greek novel", thus pointing to the exchange between these cultures and how they have become close and sometimes extremely interrelated. However, the historical approaches to literature no longer reveal this imbrication by labeling them as "Greeks" or their authors as "Greeks of". Faced with a complex context, the central question arises for reflection: to what extent can literature in the so-called Alexandrian/Hellenistic period be considered or labeled only as "Greek"? From this inquiry, we will return to Herodotus and theorists like Maria Regina Cândido and Susan Stephens to unravel the theme.

KEYWORDS: Eurocentrism; Antiquity; Hellenistic period; African literature; Greek novel.

$\mathrm{O}$ contato entre a cultura helênica e as culturas que habitavam a África da Antiguidade apresenta muito mais inter-relações do que alguns rótulos e abordagens histórico-literárias podem deixar transparecer. Quando se pensa uma Literatura Africana que se expressa em grego, não se faz referência apenas à particularidade do local de produção desse conteúdo literário e da língua em que este é elaborado, mas a todos os possíveis agenciamentos que os encontros entre etnias puderam provocar na produção literária da antiguidade. 
Ao retomar esse tema tão querido e importante dentro dos estudos literários da antiguidade, proponho igualmente uma tomada de posição perante as convenções da história da literatura, em especial da Literatura Grega, que tende a rotular as produções de outros contextos culturais como "gregas" e seus autores como "gregos de", ou seja, mesmo fora do ambiente estritamente helênico, eles ainda seriam gregos. A inalienável marca helênica está expressa, de fato, na língua e em modelos literários, mas poder-se-ia, de fato, dizer que se trata de uma literatura apenas grega?

Há cerca de quinze anos, eu tive a alegria de ouvir da professora Laura Padilha, referência fundamental para os estudos de Literatura Africana de Expressão Portuguesa, uma pergunta retórica, uma provocação a refletir sobre os rótulos e sobre o "branqueamento" e eurocentrismo da história, em sentido amplo, e da história literária: onde fica o Egito? Eis a pergunta. O Egito paira e é deslocado imageticamente da África. O Egito, todavia, fica na África e, vale lembrar, foi também governado por uma dinastia Núbia durante algum tempo, além de dinastias egípcias e a dinastia Lágida, oriunda da Grécia. O Egito teve o Nilo habitado também por Etíopes ao longo do período helenístico e imperial romano. Assim, a grande questão suscitada pela pergunta é: em que medida a literatura feita no chamado período Alexandrino/Helenístico pode ser considerada ou rotulada apenas de "grega"? Procurei refletir sobre esse tema no livro Sob a efigie de Serapis: Alexandria do Egito e a expressão grega de uma multiculturalidade em África. No presente trabalho, retomo o estudo realizado no livro e incluo a percepção que completa tal questão: há como negar que rotular toda essa produção como "Literatura Grega", sem refletir sobre as inter-relações presentes na produção desses discursos, seria uma abordagem é etnocêntrica?

Inicia-se a reflexão proposta aqui, em primeiro lugar, retomando dados iniciais que apontam as relações entre Hélade e África na Antiguidade. Para tanto, um dos autores a ser pensado é Heródoto. Entretanto, mesmo antes dele, a arqueologia e, especialmente, a pintura mural são os primeiros elementos a traduzirem em imagem a presença do Egito, por exemplo, como referencial estético para a pintura mural de um palácio em Acrotera, algo que diz muito a respeito de como o Egito era percebido pelos gregos.

Acrotera é a acrópole da ilha de Thera, atual Santorini. Essa ilha sofreu com uma erupção vulcânica e teve suas construções relativamente preservadas por suas cinzas que se depositaram ali em grande quantida- 
de, evento que ocorreu em cerca de 1500 a.C. Vale dizer que não foram encontrados dados de vítimas decorrentes dessa erupção, pelo menos na cidade soterrada pelas cinzas. Ao contrário, indícios arqueológicos apontam a evacuação da cidade e o estoque de víveres, provavelmente, em decorrência da previsão de um retorno dos habitantes à cidade, algo que não aconteceu.

A cidade apresenta uma construção palaciana que dialoga arquitetonicamente com as construções minoicas encontradas em Creta. Suas paredes foram decoradas com afrescos coloridos e com motivos cotidianos e decorações de folhagens. Uma das salas apresenta uma decoração feita a partir das imagens de papiros, plantas que são características das margens do Rio Nilo, no Egito, e que também são motivos decorativos em palácios egípcios. A partir das imagens abaixo, figuras 1 e 2, ${ }^{1 / 2}$ percebe-se a semelhança entre as decorações.

Figura 1

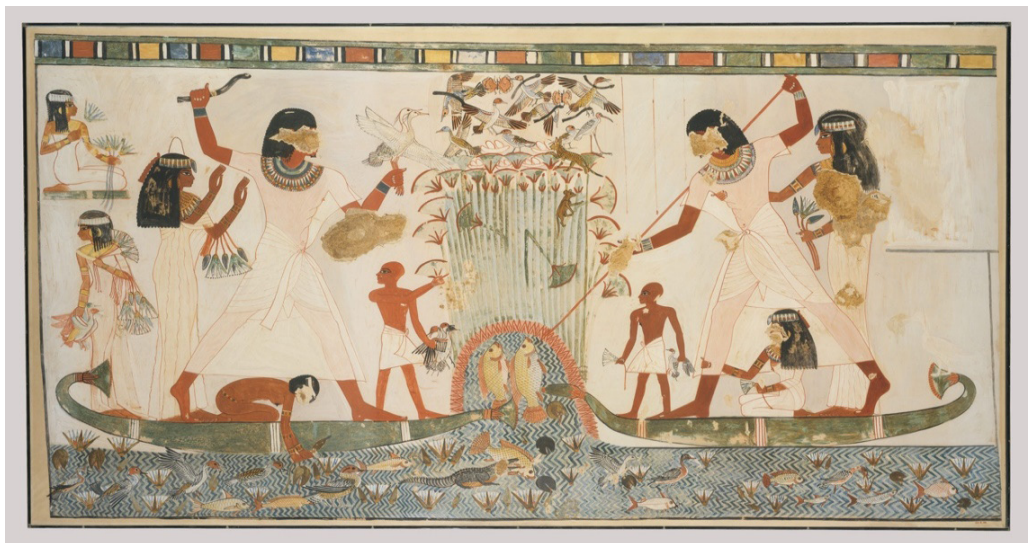

1 "Menna and Family Hunting in the Marshes, Tomb of Menna". Cópia de pintura mural datada entre 1400 e 1352 a.C.. In: https://www.metmuseum.org/toah/ works-of-art/30.4.48/. Acesso em 12/05/2019.

2 Parede decorada abrigada no Museu Arqueológico Nacional, Atenas. Fonte: acervo pessoal. 
Figura 2

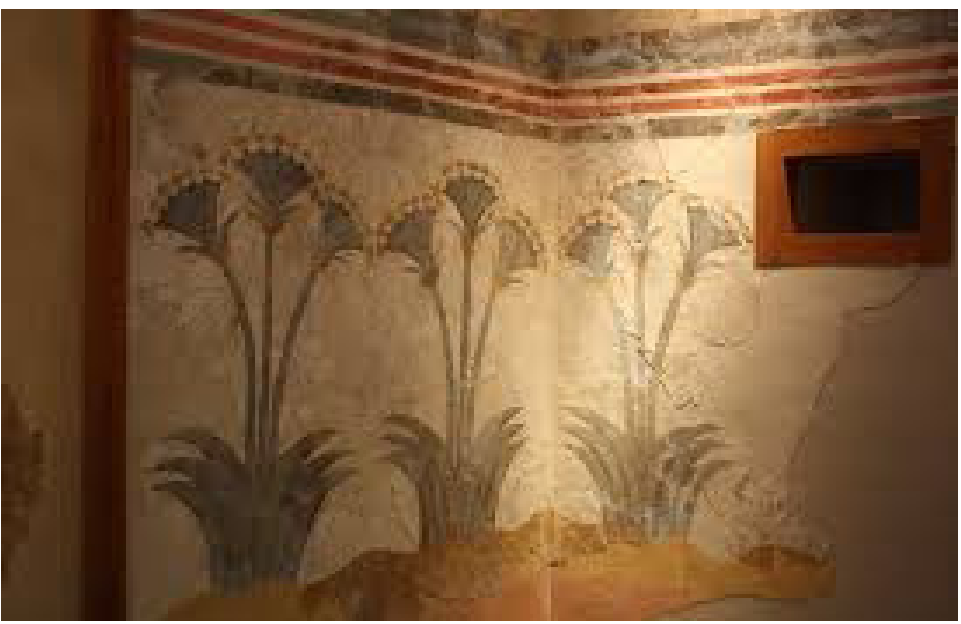

A primeira imagem é uma cópia de pintura mural retirada de uma tumba egípcia, datada entre 1400 e 1352 a.C. A segunda imagem foi encontrada nas escavações de Acrotera. Há uma diferença interessante entre as duas: a base da imagem decorativa grega apresenta uma folhagem extra que não se vê na representação de papiro egípcia.

Abordou-se a cultura material como exemplo dessas trocas culturais para que se pudesse refletir a respeito de quão antigos são as inter-relações entre Egito e Grécia, anteriores mesmo aos primeiros escritos que nos chegaram. Vale ainda ressaltar o fato de o Egito ser mencionado já na Odisseia, por exemplo, bem como os etíopes, diga-se de passagem.

Em Heródoto, verifica-se que a observação dos egípcios se dá de maneira muito positiva:

IV — Quanto às coisas humanas, todos são unânimes em afirmar que os Egípcios foram os primeiros a estabelecer a noção de ano, dividindo este em doze partes, segundo o conhecimento que possuíam dos astros. Parecem-me eles nisso muito mais hábeis do que os Gregos, que, para conservar a ordem das estações, acrescentam ao começo do terceiro ano um mês intercalado, enquanto que os Egípcios fazem cada mês de trinta dias, acrescentando a todos os anos cinco dias mais.

XXXV — Estender-me-ei mais no que concerne ao Egito, por encerrar ele mais maravilhas do que qualquer outro país; e não existe lugar onde se vejam tantas obras admiráveis, não havendo palavras que possam descrevê-las (Heródoto, 1950). 
Interessante perceber em uma obra do período helenístico, ou seja, em torno do III século a.C., que o Egito e a cidade de Alexandria são descritos em termos muito próximos aos utilizados em Heródoto. Isto ocorrerá na obra de Herondas, mimiambógrafo que utilizará essa argumentação para exaltar a cidade governada pela estirpe Ptolomaica:

Há dez meses partiu Mandris para o Egito

E nem uma carta enviou a você, mas esqueceu-se e bebeu de uma outra.

E que lá é a morada da deusa; pois tudo

que existe e é produzido, está no Egito:

riqueza, educação, força, serenidade, espírito, espetáculos, filósofos, ouro, jovens, domínio sagrado dos deuses irmãos, o rei notável, o Museu, vinho, tudo de bom que possa desejar, mulheres (...) (Lima, 2009, p.57)

Voltando à cultura material, verifica-se em alguns vasos áticos do V século a.C. a presença etíope na imagética helênica. Escolho aqui observar um vaso em particular. Trata-se de um vaso ático de dupla face (januforme) $)^{3}$ datado do século $\mathrm{V}$ a.C., que apresenta retratados um rosto de homem negro e de mulher branca. ${ }^{4}$

Figura 3

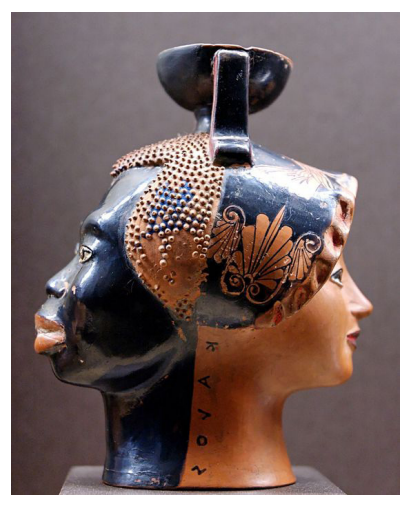

3 Em forma de Janus, denominação retirada da figura do deus de dupla face dos romanos, Janus.

4 Vaso januforme atribuído a Skythes, ca. 520-510 a.C.. Museu do Louvre. Fonte: https://br.pinterest.com/pin/499195939940390034/?lp=true. Acesso em $11 / 05 / 2019$. 
É interessante observar esse objeto de arte (figura 3) como algo que transita pela alteridade e pela dicotomia "nós/outros". Pensa-se assim pelo fato de termos uma arte feita em ambiente ático (grego) a retratar tanto uma mulher grega quanto um homem etíope. Entretanto, se há elementos díspares no retrato feito em peça de extrema qualidade, há, igualmente, uma inscrição grega que se insere perfeitamente na cultura helênica. Antes de falar dessa inscrição, vale um relato interessante sobre o tema, na perspectiva histórica. Em palestra realizada na $\mathrm{UFRJ}^{5}$, a professora Maria Regina Cândido chama a atenção para uma postura etnocêntrica de uma estudiosa norte-americana, Beth Cohen, ao indicar que o vaso de dupla face do V século a.C. acima reproduzido retrataria um escravo e uma prostituta.

A pergunta que imediatamente foi feita pela própria palestrante foi "por que um escravo necessariamente"? E por que, ao lado do homem negro, deveria haver, necessariamente, uma prostituta?" O vaso, para além de ser um objeto de fina cerâmica, trazia escrito o termo kalós, ou seja, "belo" e, por extensão, "nobre". Esse detalhe inviabiliza a leitura do vaso como retrato de um escravo e de uma prostituta, afinal, o temos kalós se refere à esfera social dos aristoi, da aristocracia helênica. Na verdade, a Atenas de Péricles era frequentada por nobres etíopes, admirados pela sua estatura e compleição física. Mas o que fez Cohen acreditar que o retrato de um homem negro só poderia ser o de um escravo? E que a ele deveria estar associada a imagem de uma prostituta? Trata-se, a meu ver, de uma postura etnocêntrica, pois a estudiosa toma a sua história e o processo de constituição de sua nação - em que o negro chegou como escravo e a mulher associada a ele não poderia estar em uma esfera social "positiva", além de não ser aceitável a união entre um homem negro e uma mulher branca - como o parâmetro de leitura de outras sociedades e de outros tempos.

Antes de prosseguir na reflexão a respeito da postura de Cohen, é importante discutir o termo etnocentrismo. A etimologia da palavra aponta para a ideia de centralização na etnia, ou seja, o conceito de etnocentrismo carrega a crença de que um grupo e sua cultura são superiores a outros grupos e suas culturas. E são superiores por se considerarem centrais. Justamente por isso, por se entender a própria cultura como parâmetro

5 Palestra realizada em mesa-redonda, no dia 10 de maio de 2019, durante a realização do II Seminário Nacional de Pesquisa em Graduação de Estudos Clássicos - SENPEGEC. 
único, tal postura não percebe o "outro" e sua cultura como algo de valor, sobretudo, quando a cultura do "outro" coloca em xeque a sua própria.

Vale tomar aqui uma passagem de Laraia, em Cultura um conceito antropológico:

A nossa herança cultural, desenvolvida através de inúmeras gerações, sempre nos condicionou a reagir depreciativamente em relação ao comportamento daqueles que agem fora dos padrões aceitos pela maioria da comunidade. Por isto, discriminamos o comportamento desviante (LARAIA, 2001, p. 65).

Talvez a percepção de Cohen fosse calcada nessa herança cultural, em que o negro está no lugar depreciativo de um outro subalterno. Ele não poderia ser nada além de um escravo naquele contexto, estaria fora do padrão culturalmente herdado. Todavia, escapou à historiadora o fato de que a escravidão na antiguidade não estava ligada à etnia, à cor da pele, mas ao fato de se perder uma guerra, por exemplo. Novamente, retomo Maria Regina Cândido, mas agora a partir de um recente artigo publicado na revista Cadernos de História:

Tanto Heródoto quanto Pausânias e Estrabão construíram narrativas históricas que nos permitem apreender como os gregos interagiram com os não gregos, como estabeleceram contato com os considerados bárbaros por não falarem a língua grega e como transitaram pelas regiões banhadas pelos mares Egeu, Mediterrâneo e Negro. O que nos chama a atenção no discurso e na narrativa desses autores é a ausência de disforização proveniente da diferença em relação à tonalidade da cor da pele. Tal fato ratifica que o conceito de raça e de referências à cor da pele ou etnia tornam-se temas de debates historiográficos no século XIX (CANDIDO, 2018, p. 24).

Ou seja, a abordagem realizada por Cohen foi impregnada por um caráter etnocêntrico, o qual imprimiu na percepção de um objeto artístico helênico uma concepção anacrônica da figura do negro. Tal percepção fez com que se deixasse de observar o detalhe da convivência cultural que leva o outro para dentro da criação artística, ao mesmo tempo que o insere, pela escrita, em um patamar muito específico da cultura grega ateniense da época. Vale ressaltar que esta percepção da obra de arte em questão só é possível através de uma abordagem que seja, necessariamente, relativista. Ou seja, um modo de abordar que se obrigue ao exercício de perceber como a cultura ateniense do V século a.C. tinha sua organização própria, dentro de uma rede de intercessões muito específicas, e que 
sua lente também lia o outro através de seus parâmetros, diferentes daqueles que pautam a cultura contemporânea, ainda tão eurocêntrica e ligada a uma construção patriarcal branca. Tais parâmetros ainda percebem no negro apenas a figura do escravo e, associado a ele, a mulher em situação degradada, prostituída.

Ao abordarmos esse objeto artístico como um produto de uma cultura ática do $\mathrm{V}$ século a.C. e percebermos a presença da figura etíope ao lado de uma mulher grega, com a marca do epíteto aristocrático, em uma peça de alto valor monetário e artístico no contexto de sua produção, é de vital importância para o pesquisador, no processo de "olhar, ouvir, escrever", estar disciplinado pela episteme relativista da antropologia. Apenas desse modo, é possível escapar à armadilha etnocêntrica de valoração a partir de sua própria lente/cultura e ser capaz de perceber como as estruturas se repetem, pensando com Levi-Strauss, ou como a organização simbólica opera.

A partir da reflexão acima, pretendo ressaltar a presença relevante de elementos representativos da cultura africana registrados por dados da cultura grega, seja em termos arqueológicos e na cultura material, seja na literatura anterior ao período helenístico.

Evidentemente, esses são dados de uma relação de trocas comerciais e políticas no âmbito da cultura helênica antes da expansão promovida por Alexandre Magno. O que ocorre, no entanto, quando há um deslocamento dos elementos que constituem a cultura grega para o ambiente egípcio? A língua permanecerá a mesma? E os modos de expressão literária - foco principal do presente artigo - podem ser compreendidos como exclusivamente gregos ou cria-se outra percepção do ser que fala grego, helenízei, mas se autodenomina egípcio? E vale destacar mais uma questão ainda: como abordar a produção desse período sem cair na armadilha do etnocentrismo?

Inicialmente, é preciso compreender como se dá essa presença mais efetiva da língua e da cultura gregas no ambiente egípcio e quais as consequências da fundação de Alexandria do Egito. A fundação da cidade está necessariamente ligada à imagética de Alexandre Magno, o "libertador" do Egito e restaurador da religião que cultua Isis e Osíris. Em torno de 331 a.C., o recém-reconhecido faraó do Egito, Alexandre, depois de um sonho profético, teria desenhado na areia a planta baixa daquela que viria a ser a maior dentre as Alexandrias por ele fundadas: a Alexandria do Egito. É importante pensar na atitude do conquistador que assume o 
título local de faraó, ao invés de impor algo que fosse concernente apenas à cultura helênica. Nota-se que essa atitude se repete no modus operandi de Alexandre Magno, uma vez que se fez reconhecer igualmente "grande rei" no ambiente medo-pérsico.

Deinócrates de Rodes será o responsável pela concretização do primeiro desenho arquitetônico de Alexandria do Egito. Sabe-se que a cidade era dividida em cinco setores, nomeados de acordo com as primeiras cinco letras do alfabeto grego. A construção da cidade, pelo menos em sua primeira fase, parece ter sido concluída sob o domínio Lágida, mais exatamente durante o reinado de Ptolomeu Filadelfo (285-246 a.C.). Ou seja, Alexandre e seu general que assumiu a Satrapia do Egito - Ptolomeu, filho de Lagos - , já estavam mortos.

Alexandria era uma cidade consideravelmente grande para os padrões gregos e poderia ser vista como uma megalópole da Antiguidade. Sua arquitetura está muito mais próxima das cidades egípcias e orientais, em que se apresentam largas avenidas e um grande número de monumentos. Ou seja, mesmo na arquitetura, percebe-se que os encontros culturais já se agenciam.

Em A cidade na história, Lewis Munford fala da megalópole Alexandrina e remete à ideia de que a cidade grande, megalópole, funciona como um lugar do "espetáculo":

O espaço aberto aumentado, proporcionado pela ágora maior e pelas ruas mais largas e mais compridas, deu à cidade helenística uma aparência "moderna". A rua Canópica, em Alexandria, fundada em 331 a.C., era mais de cinco vezes mais larga que a artéria habitual e tinha seis quilômetros e meio de comprimento (MUMFORD, 1998, p. 221).

Mumford chama a atenção para o fato de que a cidade helenística funcionaria como uma espécie de mostruário, onde o poder dos governantes é o espetáculo a ser visto. Ptolomeu Sóter e seus descendentes souberam se valer bastante do recurso espetacular na construção da cidade, algo que não seria muito próprio da cultura grega, mas perfeitamente aproveitado no modus operandi dos governantes egípcios que os precederam, haja vista a monumentalidade dos templos, palácios e tumbas de períodos anteriores.

Tem-se assim os dados da cidade construída no Egito por um arquiteto grego, de Rodes, mas já com um diálogo inegável com a arquitetura tradicional egípcia. Nota-se ainda que a cidade e toda a região do Egito será habitada por etnias diferentes: egípcios, gregos, romanos, hebreus, fenícios e etíopes, por exemplo. 
É importante agora passar à reflexão sobre o tema da língua grega, a qual é uma língua de origem indo-europeia ${ }^{6}$ e apresenta, segundo o filólogo grego Geórgios Babiniótis, em sua fase histórica ${ }^{7}$, quatro grandes momentos, entre esses, a fase da koiné alexandrina, que iria de 300 a.C até o século VI d.C. Nesse espaço de tempo, o grego se torna a língua de comunicação das várias comunidades do Mediterrâneo Oriental, após a expansão da cultura grega efetivada pelas conquistas de Alexandre Magno. Vale ressaltar, à guisa de exemplo, como a koiné neotestamentária, ou seja, o grego com o qual foram escritos os textos no Novo Testamento, tem uma presença marcante de vocabulário oriundo do hebraico e aramaico.

Mas o que esse dado tem de relevante para pensar a Literatura Africana de expressão grega? Ele é relevante pelo fato de percebermos como o grego passa a ter mais contato com outras línguas e a ser falado por outros povos. Esse processo faz com que sua diversidade lexical se amplie e, sobretudo, que aqueles que se expressam em grego, embora o façam, não se percebam como indivíduos a serem identitariamente reconhecidos como "gregos de algum lugar". Em verdade, esses indivíduos se reconhecem como egípcios, etíopes, sírios que pertencem a uma comunidade linguística helênica e se autorreconhecem como egípcios, etíopes, sírios. Diante desses dados, nota-se como o grego Alexandrino é marcado, justamente, pelos contatos multiculturais provocados pela expansão linguística helênica.

Percebe-se, pois, que não se pode cair na armadilha etnocêntrica de pautar a produção apenas pelo rótulo "Literatura Grega", uma vez que nem mesmo os falantes dessa língua se autointitulam simplesmente gregos. Mas de onde vem essa afirmação? Onde é possível encontrar um indivíduo falante da língua grega que não se autonomeie "grego do Egito", por exemplo? Na própria literatura.

Alexandria, longe de ser apenas um centro repetidor de modelos da Literatura Grega anterior, é um celeiro de experimentações literárias e o locus de nascimento das narrativas de aventuras que a História da Literatura nomeará de "romances gregos", por exemplo. Será ainda o ambiente em que um poeta, pela primeira vez na literatura dita Ocidental, irá clamar pela originalidade.

Sobre a literatura primeira produzida na Alexandria do Egito, é cer-

$6 \mathrm{O}$ indo-europeu é considerado um tronco do qual línguas aparentadas surgiram e essas famílias linguísticas são comumente atreladas a partes da Ásia e da Europa. 7 Ou seja, já sendo uma língua plenamente formada. 
to que há a presença de modelos gregos herdados e emulados. Entretanto, como já mencionei e demonstrei, através de exemplos no presente artigo, as correlações entre Grécia e Egito - que é África, vale frisar - já haviam sido consolidadas desde muitos séculos antes da fundação de Alexandria do Egito.

Stephens, em uma obra de grande relevância para o tema em tela no presente estudo, aponta os traços da cultura egípcia que emergem nas construções literárias alexandrinas. Seu livro Seeing double aponta a necessidade de uma abordagem da literatura produzida em Alexandria com uma lente diferenciada, uma "lente dupla", a qual seja capaz de perceber a moldura do modelo literário helênico e igualmente de compreender que há uma contribuição indelével e de grande potência por parte da cultura egípcia a essa literatura. Vale lembrar novamente que os encontros culturais já haviam criado religiões sincréticas com contribuições tanto egípcias quanto gregas:

Para um alexandrino, o Hórus grego era Apolo (e vice-versa), do mesmo modo, Osíris era Dioniso e Ísis era Demeter. Divindades que em outras partes do Mediterrâneo tinham mitologias distintas e separadas, no Egito, já eram parte do mesmo campo discursivo, logo a narrativa sobre um estava predisposta a convergir para a do outro. (STEPHENS, 2003, p.8-9. Minha tradução)

Como comento em meu livro Sobre a efígie de Serápis, Stephens afirma que o sincretismo e a alusão ao Egito já está presente dentro da cultura grega e, justamente, será tal presença que facilitará a acomodação dessas duas "lógicas culturais" na produção literária Alexandrina, seja ela em verso ou em prosa (LIMA, F. L., 2009, p.26).

Quando penso nessa lente dupla de que Stephens fala, necessariamente, penso na imagem da lente utilizada por Benedict (apud Laraia, 2001) ao falar do trabalho do antropólogo. Nesse ponto, a postura relativista que norteia os estudos antropológicos pode nos auxiliar numa releitura da literatura produzida em Alexandria, em que não bastam os parâmetros gregos utilizados a partir de um olhar europeu etnocêntrico. É preciso buscar outro modo de ver essa produção, ou seja, partir da postura relativista proposta anteriormente na presente reflexão.

Ao compreendê-lo como uma ideia-valor que é princípio básico do conhecimento antropológico, ou seja, sua episteme, constata-se o relativismo, dentro da percepção das culturas diversas, tal qual uma ideia que pode ser definida como uma compreensão de que cada cultura terá sua 
organização própria e não poderá estar condicionada a um juízo de valor feito por referenciais externos a ela. Ou seja, a ótica pela qual uma cultura é abordada não pode ser a de outra cultura ou ainda, para mencionar novamente Benedict (apud Laraia, 2001, p. 65), por meio de outra lente.

Dessa forma, talvez fosse melhor falar de uma literatura Egípcia de expressão grega? Seria isso mesmo ou algo mais amplo ainda. No decorrer do presente estudo, investigarei o chamado "romance grego" e será possível perceber, creio eu, como a alcunha "Literatura Egípcia" é limitadora. A presença de elementos de África para além do Egito é inegável, como no caso das comunidades etíopes mencionadas no romance Leucipa e Clitofonte. Daí a proposta de uma Literatura Africana de Expressão Grega: uma literatura que lida com os encontros culturais de elementos de África, a partir de um ponto da África (o Egito), e é expresso por molduras linguísticas gregas que já sofreram algum tipo de interferência desse espaço de enunciação.

$\mathrm{O}$ romance de aventuras de Aquiles Tátius será o corpus dessa investigação de uma forma literária, a meu ver, característica da Literatura Africana de Expressão Grega. O autor e sua obra, Leucipa e Clitofonte ou Fenícias $^{8}$ são pouco conhecidos do público leitor brasileiro, embora já haja uma tese de doutorado que contempla o estudo e tradução da obra no âmbito brasileiro.

Vale citar um trecho sobre Tátius, retirado de meu livro Sob a efigie de Serápis.

O autor, segundo as informações da edição da Loeb Classical Library, seria um grego de Alexandria do Egito. Se passarmos rapidamente por este trecho, como muitas vezes fiz anteriormente, deixaremos escapar as implicações dessa denominação. O que significa ser um "grego de Alexandria"? Há esse tipo de classificação na Antiguidade ou trata-se de uma classificação criada pela história? A partir da tese de Lobianco, vemos que, juridicamente, sob a dominação romana a uma diferença entre alexandrino e egípcio. $\mathrm{O}$ curioso é notar que o texto apresenta personagens notadamente envolvidos com a cultura helenística, que, no entanto, apresentam-se como Sidônios, Fenícios e Egípcios (grifo meu - LIMA, 2009, p.61).

Ou seja, por mais que houvesse uma nomenclatura jurídica no âmbito da administração romana que diferenciava o alexandrino do egípcio,

8 Este último seria o título perdido da obra. Cf. Holzberg. The Greek Novel. Londres: Routledge, 1995, p.86. 
o texto literário nos apresenta algo diferente, como veremos através do próprio escrito de Aquiles Tátius.

Ainda falando do autor, é relevante pensar nas suas origens, por mais obscuras que sejam. Não há muita clareza no que tange, nem mesmo, a seu nome: alguns textos medievais chamaram-no de Statius, embora o autor seja mais citado como Tátius. Procurar saber as origens de seu nome é importante para afirmar ou não as implicações multiculturais da produção literária Alexandrina. Niklas Holzberg propõe entender o nome do autor ligado ao étimo de "Thoth", nome do deus egípcio, ou seja, poderia ser mais um caso de um "grego do Egito" que é, verdadeiramente, um egípcio.

Também é importante falar desse gênero que aparece, pela primeira vez na literatura escrita em grego, no ambiente alexandrino. $\mathrm{O}$ "romance grego" é um texto ficcional em prosa que apresenta, em geral, as aventuras de um casal apaixonado que é separado por vicissitudes. Encontramos elementos de retórica, a tensão trágica, a intervenção divina, em narrativas que terminam com "final feliz" para seus protagonistas, criaturas belíssimas em termos de aparência e caráter. É importante suscitar outra questão que mereceria investigação: o Egito tem, em sua literatura, narrativas de aventura também. Um dado como esse é relevante para pensar como esse modo de escrever surge no âmbito da língua grega, justamente, no Egito.

A narrativa de Tátius é vista como um romance de aventura. Curiosamente, é um texto narrado na primeira pessoa, a qual é precedida por uma descrição de uma imagem pintada em um templo de Astarte ${ }^{9}$, localizado em Sidon. O quadro retrata o rapto de Europa e, como é recorrente nos romances de aventura gregos, a razão de toda a aventura é o Amor. A voz narrativa que apresenta a história do casal Leucipa e Clitofonte apresenta o quadro do rapto de Europa e dos encontros e desencontros desencadeados pelo deus Eros, realizando uma espécie de mis-en-abîme - uma micronarrativa - que parece espelhar a grande narrativa do romance. É importante notar como o diálogo que antecede a narrativa em primeira pessoa empreendida por Clitofonte tem por motor um comentário acerca de Eros, deus que domina céus, terras e mar. Clitofonte falará sobre as dores que padece por conta do deus. Assim, a voz narrativa que inicia o romance pede a Clitofonte que conte seu mýthos erotikós, sua narrativa de amor.

Clitofonte é um narrador intradiegético, ou seja, está presente ele mesmo na narrativa que conta, o que faz dele um narrador que tem ciên-

9 Divindade fenícia que corresponde a Afrodite dos gregos. 
cia apenas de parte dos acontecimentos. Tomo agora a apresentação de Clitofonte na narrativa:

Eu sou de família Fenícia, minha pátria é Tiro, meu nome Clitofonte, tenho por pai Hípias, Sóstratos por tio, mas este era meio-irmão de meu pai, por parte paterna. A mãe de meu tio era de Bizâncio e a de meu pai era de Tiro. (L.C., 3.1.) ${ }^{10}$

Diante do trecho destacado, observa-se como o narrador apresenta a si e a sua família como fenícios e, ao longo do texto, vê-se como o ser fenício traz também o dado de falar a língua grega. O uso do grego seria uma das justificativas para que a historiografia literária pudesse utilizar a classificação "grego de algum lugar". É interessante verificar como um filósofo místico nascido na Assíria, Jâmblico, que escreve em grego, é identificado como "assírio", enquanto um filósofo nascido no Egito (e não em Alexandria) e expoente do neoplatonismo é considerado grego do Egito, caso de Plotino. Esse é um dado curioso para a reflexão sobre as escolhas dos rótulos étnicos na classificação de autores da antiguidade.

Voltando à apresentação de Clitofonte, percebe-se que ele não se identifica como um grego da diáspora, mas como fenício. Dessa forma, posso dizer que dicotomias ocidente-oriente, gregos-fenícios e gregos-egípcios não são tão evidentes no período alexandrino, especialmente, da maneira como é posta pela história.

$\mathrm{O}$ enredo do romance Leucipa e Clitofonte apresenta a história de um jovem bem nascido - Clitofonte - apaixonado por Leucipa, uma moça de família abastada. Por conta de vários mal-entendidos, típicos dos "romances gregos", o casal acaba por fugir da casa do pai do jovem para, mais tarde, consumar seu casamento. Como em todo romance de aventuras em grego do período, os enamorados passarão por percalços e perigos como naufrágios, sacrifícios humanos, atuação de bandoleiros. A protagonista, Leucipa, é dada como morta duas vezes e Clitofonte se casa com outra mulher, acreditando que a amada está morta. Ocorrem inúmeras viagens, entre as quais cabe destacar a feita ao Egito.

10 Tradução livre. Todos os trechos aqui transcritos do romance Leucipa e Clitofonte foram traduzidos por mim a partir do texto grego da edição Loeb (Warmington, E. H. (ed.), Achilles Tatius. Cambridge (MA)/Londres: Harvard University Press, 1989, 461 páginas. 
O cenário pelo qual as aventuras dos protagonistas do romance em tela se desenrolarão será, em parte, o rio Nilo, ambiente característico do Egito e, como já era de se esperar, a cidade de Alexandria.

Proponho destacar algumas passagens da obra que ressaltam a constituição identitária e de comunidade das personagens, especialmente do protagonista Clitofonte e de Menelau, outra figura que será apresentada de maneira relevante para a leitura aqui proposta.

No livro III, após um naufrágio, Leucipa e Clitofonte alugam um barco para chegar a Alexandria, tendo por rota de viagem o magnífico rio Nilo. Entretanto, como sempre ocorre algo, dessa vez, "bandoleiros" atacam o barco, como mostra o fragmento abaixo:

$\mathrm{E}$, enquanto isso, a terra ficou repleta de homens assustadores e selvagens, todos enormes, de cor negra, não como os da Índia, mas como um mestiço etíope, com cabeças raspadas, pés pequenos e grandes corpos. Todos falavam uma língua bárbara/estranha. (L\&C, livro III, 9)

Um pouco mais à frente, lê-se o lamento de Clitofonte aos deuses e daimones:

Agora, entregaram-nos nas mãos de ladrões egípcios, e assim não temos a sorte de implorar. A (minha) fala pode se comunicar com um ladrão grego (...) mas agora com que fala suplicar? (L\&C, livro III, 10)

O discurso de Clitofonte sinaliza pontos de estranhamento em relação aos bandoleiros, os quais não falariam grego e seriam egípcios e etíopes, ou seja, haveria um dado étnico diverso que estaria marcado na fala que é outra e impede a súplica. Os estereótipos apresentados - homens negros assustadores e selvagens, cuja fala não pode ser compreendida compõem a visão de Clitofonte, um rapaz inexperiente que jamais deixara Tiro antes dessa aventura. A passagem em questão pode dar a ideia de que há uma diferença nítida entre gregos e bárbaros, como argumentei em outro texto (LIMA, 2009, p. 71). Não obstante, o próprio desenvolvimento da narrativa mostra o outro lado da moeda e desfaz o estranhamento provacado pela cultura do outro que assusta Clitofonte. Menelau, amigo do casal de protagonistas, que havia se perdido dos amigos após o naufrágio, intervém na situação. Vale ressaltar que Menelau é egípcio, como ele mesmo lembra a Clitofonte, ao explicar como salvou a amiga Leucipa de um sacrifício ao deus dos bandoleiros: 
Ele disse: sabe que sou egípcio por parte de minha família, isso eu contei a você no navio. Desse modo, a maior parte de minhas propriedades está em torno destas comunidades e seus chefes me conhecem. Quando então sofremos o naufrágio, as ondas nos levaram às praias do Egito, fui capturado juntamente com Sátiro(...). Como fosse conduzido diante do chefe dos ladrões, reconhecendo-me alguns dos ladrões, libertaram-me das correntes, falaram a mim com ânimo, condoendo-se por mim, como se fossem familiares (oikeîn). (L\&C, livro III, 19)

Diante da fala da personagem Menelau, percebe-se como o Egito se constitui de outro modo, como uma comunidade composta por diversas etnias e culturas que convivem e criam uma nova cultura em África. Nem grega, nem apenas egípcia ou etíope, mas desse mundo em que o termo "familiar" pode ser aplicado, mostrando a construção de uma convivência outra e de uma constituição cultural consequentemente diversa. O contraste entre Menelau e Clitofonte reside na vivência cultural diferenciada. Retomo, então, um argumento utilizado anteriormente por mim que vale ser repetido aqui:

Assim o egípcio que fala grego não estranha, nem é estranhado, pelos bandoleiros que parecem etíopes, mas que o próprio Clitofonte chama de egípcios. Mais ainda, ao ser reconhecido, Menelau é tratado como um familiar sofrido, que merece ser recebido com ânimo pelos seus. O uso do termo oikeîon deixa clara a ligação de familiaridade, de intimidade, pois são homens interligados pelo conceito de oíkos, casa, família. Assim as fronteiras entre as várias populações que habitam o Egito acabam por mostrarem-se frágeis e artificiais. As fronteiras identitárias não são absolutamente claras, como a historiografia nos ensinara artificialmente, neste espaço e tempo do Mediterrâneo Oriental, percebemos que a dicotomia grego-bárbaro, que poderia inicialmente ser reforçada pelo olhar de Clitofonte, dissipa-se pela convivência familiar entre populações que vivem num mesmo Egito (LIMA, 2009, p. 72).

Voltando à imagem da lente, cunhada por Benedict e mencionada por Laraia, referencial antropológico do presente estudo, gostaria de convidar o leitor a perceber como é preciso desconstruir os etnocentrismos para podermos apreciar com lentes novas esse cenário da antiguidade, tão múltiplo e com divisões muito menos evidentes do que a historiografia literária gostaria de imprimir. São muitos os encontros e a formação da 
literatura que se expressam em grego, como é possível perceber pelos breves exemplos apresentados no presente artigo.

É preciso provocar uma reflexão através da qual repensemos as classificações históricas e percebamos o quanto elas são carregadas de conceitos pré-moldados por uma postura etnocêntrica. Daí a importância de estudos que colocam em xeque algumas verdades históricas de base eurocêntrica. Por isso, é importante questionar o lugar, o modo e o conteúdo das produções literárias do Egito Alexandrino, caldeirão cultural em África que se expressa em grego e oferece muita matéria de reflexão sobre uma cultura em que as diversas etnias podem se reconhecer como familiares, como fez Menelau, nosso egípcio do romance de Aquiles Tátius, um representante excelente dessa Literatura Africana de Expressão Grega.

\section{REFERÊNCIAS}

BULlOCH, A. Poesia Helenística. In: EASTERling, P. E. e KNOX, B. M. W. (editors) Historia de la Literatura Clásica. Madri: Gredos, 1990, vol. 1. HERODAS. Mimes. In: RUSTEN, Jeffrey, CUNNINGHAM, I.C. e KNOX, A.D. (trad. e org.)

Sob a efígie de Serápis: Alexandria do Egito e a expressão grega de uma multiculturalidade em África. Rio de Janeiro: Horus Educacional, 2009.

BERNAL, Martin. Black Athena - The Afroasiatic Roots of Classical Civilization. Londres: Vintage, 1991.

BULLOCH, A. Poesía helenística. In: P.E. Easterling e Knox, B. M. W. Historia de la literatura clásica. Madri: Gredos, 1990, vol I.

CANDIDO, Maria Regina. A África Antiga sob a ótica dos clássicos gregos e o viés africanista. In: Cadernos de História, Belo Horizonte, v. 19, n. 30, 1 o sem. 2018.

EDMONDS, J. M. The Greek Bucolic Poets. Londres e Cambridge: Harvard Universyt Press, 1991.

MOKHTAR. G. História geral da África - II A África Antiga. Rio de Janeiro:Ática/Unesco, 1983.STEPHENS. Susan A. Seeing Double - intercultural 
poetics in Ptolomaic Alexandria. Berkeley: UCP, 2003.

MUMFORD, Lewis. A cidade na história. São Paulo: Martins Fontes, 1998.

STEPHENS, S. A., Seeing double - intercultural poetics in ptolomaic Alexandria.

Berkeley/Londres, University of California Press, 2003, p.8-9.

Recebido em: 01/08/2019

Aceito em: 30/09/2019 